Jurnal Konstruksi Hukum | ISSN: 2746-5055

Vol. 2, No. 1, Januari 2021 Hal 1-4 | Tersedia online di https://www.ejournal.warmadewa.ac.id/index.php/jukonhum

DOI: https://10.22225/jkh.2.1.2956.1-4

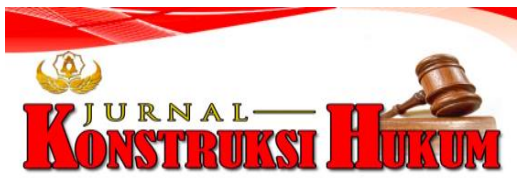

\title{
PERLINDUNGAN HUKUM TERHADAP HAK-HAK KORBAN DALAM PERDAGANGAN MANUSIA DARI PERSEPEKTIF HAK ASASI MANUSIA
}

\author{
Agus Yogik Palguna, I Nyoman Gede Sugiartha, Luh Putu Suryani \\ Fakultas Hukum Universitas Warmadewa, Denpasar-Bali, Indonesia
}

\begin{abstract}
Abstrak
Tindak pidana perdagangan orang sering terjadi di kalangan perempuan dan anak. Kasus ini kebanyakan dari kalangan perempuan dewasa; hal ini disebabkan karena tuntutan kebutuhan (ekonomi kurang) sehingga perdagangan orang sering terjadi. Pemerintah harus memberantas kasus ini dan memberikan perlindungan hukum bagi korban tindak pidana perdagangan orang supaya perempuan dan anak tidak diberlakukan sewenangwenang oleh pelaku perdagangan orang. Tipe penelitian yang digunakan adalah yuridis normative; suatu penelitian yang pembahasannya didasarkan undang-undang dan bahan-bahan hukum. Hasil analisis menunjukan bahwa sanksi pidana yang di berikan kepada pelaku haruslah sanksi yang benar-benar yang memberikan efek jera, supaya pelaku tidak mengulangi kesalahannya. Selain itu, dengana adanya saknsi dapat mengurangi kasus tindak pidana perdagangan orang terhadap perempuan dan anak, dan tidak ada yang memberlakukan perempuan dan anak dengan sewenang-wenang, dan tidak lagi membuat perempuan dan anak menjadi korban dari perdagangan orang. Supaya anak dan perempuan bisa menjadi generasi penerus bangsa yang menjadi kebanggaan bagi diri mereka sendiri dan orang lain.
\end{abstract}

Kata Kunci: Perlindungan Hukum, Perdagangan manusia, Hak Asasi Manusia, sanksi

\begin{abstract}
The crime of trafficking in persons often occurs among women and children. This case is mostly among adult women; this is due to demands (less economic) so that trafficking in persons often occurs. The government must eradicate this case and provide legal protection for victims of trafficking in persons so that women and children are not arbitrarily treated by traffickers. The type of research used is juridical normative; a study the discussion of which is based on laws and legal materials. The results of the analysis show that the criminal sanctions given to the perpetrators must be really sanctions that give a deterrent effect, so that the perpetrators do not repeat their mistakes. In addition, the existence of sanctions can reduce criminal cases of trafficking in persons against women and children, and no one treats women and children arbitrarily, and no longer makes women and children victims of trafficking in persons. So that children and women can become the next generation of the nation to be proud of themselves and others.
\end{abstract}

Keywords: Legal Protection, Human Trafficking, Human Rights, Sanctions

\section{PENDAHULUAN}

Laki-laki maupun perempuan memiliki derajat dan kedudukan yang sama sejak lahir yang tidak bisa diganggu-gugat oleh siapapun. Selain itu, manusia juga memiliki hak untuk hidup dan melangsungkan kehidupannya serta bebas dari penindasan atau yang merugikan pribadinya. Dengan kata lain, hak tersebut ditentukan dalam hakikat kemanusiaan dan demi kemanusiaan atau yang dikenal dengan istilah Hak Asasi Manusia (HAM).

HAM yang merupakan hak dasar seluruh umat manusia; sebagai anugerah Tuhan yang maha esa dan tidak bisa diganggu gugat oleh siapapun. Hak untuk hidup bagi manusia merupakan hak yang mendasari dari pribadi masing-masing, baik yang berkulit hitam atau pun kulit putih semua meliliki kedudukan yang sama di mata hukum, maka dari kita harus bisa mengahargai hak-hak seseorang. Seharusnya, dengan adanya undang-undang tentang HAM kita bisa lebih menghargai hak-hak dan kedudukan seseorang bukan berlaku yang seenaknya terhadap orang lain. Salah satu permasalahan Hak Asasi Manusia yang terjadi di Indonesia dimana kasusnya adalah perdagangan orang, perdaganggan orang ini marak terjadi di mana kasus ini sering terjadi pada perempuan dan anak, motif dari kasus ini bermacam-macm seperti penculikan, menjanjikan memberikan uang banyak kepada korban, yang sering terjadi pada kasus ini adalah perempuan dewasa di mana perempuan dewasa ini di perdaganggan untuk memenuhi hawa nafsu lekali hidung belang. Di Indonesia, kejahatan perdagangan orang mengambil bentuk perdagangan untuk tujuan eksploitasi seksual, 
pekerja rumah tangga, pekerja migran, pekerja anak, dan perkawinan pesanan yang sering terjadi di kalangan perempuan dan anak yang membuat seorang anak dan perempuan terikat dalam sebuah permain seorang pelaku dan susah bagi mereka untuk keluar dari permain tersebut.

Disarankan kepada pemerintah dan penegak hukum agar membantu memecahkan kasus tersebut agar tidak terjadi lagi penindasan bahkan kehilangan masa depan bagi perempuan dan anak. Penegak hukum harus memberikan hukum yang sepantasnya bagi pelaku perdagangan orang pelaku tidak melakukan jahatan yang lain dan dapat mengurangi kasus perdagangan orang. Dengan begitu, masa depan yang terbaik bagi perempuan dan anak. Perdagangan orang merupakan kejahatan yang sangat merusak masa depan perempuan dan anak karena kejahatan tersebut membuat perempuan dan anak harus mengikuti kemauan pelaku perdagangan orang.

Kasus perdagangan orang tidak hanya terjadi di Indonesia. Namun, kasus ini juga banayak terjadi di beberapa Negara lainnya. Kita dapat dengan mudah melihat kasus ini di manapun; seorang korban perdagangan orang harus mengikuti kemauan si pelaku dari perdagangan orang. Menurut, Dunbar (2010) bahwa perdagangan orang adalah bukan hanya tentang soal pelacuran, melainkan sebuah konteks penjual orang untuk membuat korban dengan perbuatan yang tidak semena-mena yang membuat masa depan seorang perempuan dan anak bisa hancur.

Perdagangan orang adalah suatu perbuatan yang merugikan di kalangan masyarakat dan merendahkan martabat manusia (Suhardin, 2008: 485). Saat ini sangat marak terjadi dengaan modus mengiming-imingkan uang pada korban, sehingga membuat korban tergiur untuk mengikuti kemauan dari si pelaku tindak pidana perdagangan orang. Akhirnya, korban terjerat dalam sebuah permain sipelaku tindak pidana perdagangan orang sangat sulit bagi si korban untuk bisa keluar dari sebuah permainan tersebut. Mereka dipaksa bekerja sekalipun mereka tidak suka dan harus mengikuti kemauan dari pelaku perdagangan orang, kalau tidak mereka akan diancam dan bisa merugikan bagi perempuan dan anak yang akan merusak harga diri mereka dengan melakukan suatu kerjaan yang membuat mereka terjebak dalam kerjaan yang akan merusak masa depan mereka.

Perlindungan hukum terhadap korban dari perdagangan orang sangat penting untuk diketahui. Perlindungan hukum adalah perlindungan yang diberikan terhadap perempuan dan anak dalam perdagangan orang, yang di berikan oleh pemerintah agar dapat melindungi perempuan dan anak dari perdagangan orang yang dapat merusak masa deapan mereka. Dengan adanya sebuah perlindungan hukum dari pemerintah, maka bisa mengedepankan hak-hak korban perdagangan orang yang sering marak terjadi. Dengan perindungan hukum, perempuan dan anak bisa terhindar atau keluar dari kasus perdagangan orang. Kasus ini sering terjadi dikalangan perempuan remaja dan dewasa. Bahkan mereka dijadikan sebagai pemuas seks bagi kaum lelaki yang berhidung belang. Setiap hari mereka harus melayani atau menjual harga diri mereka dengan bayaran yang cukup untuk kebutuhan kehidupan sehari-hari mereka. Kasus ini sangatlah memperhatinkan dimana perempuan dan anak menjual harga diri mereka tiap hari. Sangat disayangkan apabila kasus ini terus terjadi, maka masa depan perempuan dan anak akan hancur dan jika mereka pulang kembali dalam kehidupan mereka yang sebenarnya dalam kalangan masyarakat, sulit bagi masyarakat untuk menerima mereka kembali, karna mereka di cap dengan perbuatan yang tidak baik, maka dari itu pemerintah di wajibkan untuk memberi perlindungan hukum bagi perempuan dan anak agar mereka tidak di cap yang tidak baik oleh masyarakat supaya mereka bisa kembali melangsungkan kehidupan mereka yang sebenarnya.

Menurut Arief (2010), korban dari perdagangan orang berhak di rehabilitasi supaya mereka mendapat hal yang sepadan dengan kejadian yang mereka alami. Korban juga harus dipulihkan supaya kehidupan mereka bisa diterima di kalangan masyarakat; dan tentunya, mereka dapat melangsungkan hidup dan kehidupan mereka dengan baik dalam kehidupan bermasyarakat mereka. Terkait dengan perlindungan kepada korban perdagangan manusia, berikut beberapa penelitian terdahulu telah menganalisisnya seperti Dols, Beckmann-Mendez, McDow, Walker, \& Moon (2019); Fong \& Berger Cardoso (2010); Gerry, Muraszkiewicz, \& Iannelli (2018); Gonzalez-Pons, Gezinski, Morzenti, Hendrix, \& Graves (2020); Martinho, Gonçalves, \& Matos (2020); Mustafid (2019). Perlindungan hukum adalah suatu perlindungan yang di berikan dari pemerintah kepada korban perdagangan orang dengan adanya perlindungan hukum maka korban bisa mendapatkan hak-hak mereka kembali (Takariawan \& Putri, 2018). Mereka bisa terlindungi dari tindakan kejahtan perdagangan orang dan juga perempuan dan anak bisa membuat hal-hal yang positif kembali dalam kehidupan mereka. Berdasarkan uraian di atas, penelitian ini bertujuan untuk menganalisis 
perlindungan hukum terhadap perempuan dan anak yang mengalami tindak pidana perdagangan orang dan mengetahui sanksi hukum terhadap pelaku perdagangan orang.

\section{METODE PENELITIAN}

Tipe penelitian dalam penelitian ini adalah yuridis normatif, yaitu suatu penelitian yang pembahasannya didasarkan undang-undang dan bahan-bahan hukum (Marzuki, 2011). Tipe peneltian mengkaji suatu masalah yang dikaitkan dengan undang-undang, lalu diteliti dengan baik kasus tersebut sesuai dengan undang- undang yang berlaku. Sumber bahan hukum ini di gunakan dengan undang-undang perdagangan orang dan perlindungan hukum terhadap perempuan dan anak dalam perdagangan orang. Teknik pengumpulan bahan hukum ini digunakan dengan mengkaji suatu buku, atau literature dalam menyelesaikan kasus perdagangan orang agar bisa memberi manfaat bagi pemerintah dan masyarakat dalam suatu kasus perdagangan orang. Analis bahan hukum ini di gunakan dengan suatu kajian pustaka sesuai dengan kasus perdagangan orang.

\section{PEMBAHASAN PENELITIAN}

\section{Pengaturan Perlindungan Hukum yang Diberikan oleh Pemerintah Kepada Korban Perdagangan Manusia}

Sebuah penjelasan mengenai perdagangan manusia tentu mengarah pada sebuah penjualan orang yaitu perempuan dan anak yang salah satunya yang menjadi korban. Kejadian ini sangat marak terjadi saat ini dengan sebuah modus yang membuat korban tidak berpikir panjang. Mereka pasti akan ikut kemauan dari si pelaku. Sebagai mahluk ciptaan Tuhan, kita memiliki derajat yang sama dimana kita tidak boleh melakukan perbuatan yang semena-mena terhadap oran lain, apalagi sampai menjual sesama kita. Itu sangat membahayakan bahkan bisa merusak masa depan seseorang. Oleh karena itu, kita seharusnya menjaga hubungan baik dengan seseorang bukan melakukan perbuatan yang tidak baik terhadap orang lain.

Perdagangan orang merupakan kasus yang sangat marak terjadi terhadap perempuan dan anak. Hal ini disebabkan karena kebutuhan ekonomi korban, sehingga tidak ada jalan lain lagi selain menjual diri mereka sendiri terhadap orang lain agar bisa mendapatkan uang dan memenuhi kebutuhan hidup mereka. Seharusnya pemerintah dapat membantu kebutuhan ekonomi bagi perempuan dan anak agar mereka tidak terjerumus terhadap kasus perdagangan orang. Menurut, $\mathrm{M}$. Ali \& Nurhidayat (2011) hak asasi manusia adalah hak yang harus di pertahankan, dijunjung tinggi dan di hargai oleh orang lain bukan di rusakin oleh orang lain atau di permainkan oleh seseorang. Perlindungan hukum kepada korban seharusnya diwujudkan dengan baik. Dalam hal ini, pemerintah dapat memberikan pengaturan perlindungan hukum terhadap korban perdagangan orang, agar masa depan perempuan dan anak dapat terjaga dengan baik, bukan di rusakin atau memberlakukan orang yang tidak baik.

Suatu kasus perdagangan orang adalah kasus peculikan, pengangkutan atau modus yang mengiming-imingkan uang banyak bagi si korban maka korban akan terjerumus di dalam kasus perdagangan orang, sistem dari pemidanaan terhadap perdagangan orang harus di teliti dengan baik agar bisa memberi keadilan bagi korban perdagangan orang, para pelaku perdagangan orang harus di beri sanksi yang sepedan dengan perbuatan mereka para penegak harus sikap dalam kasus ini agar bisa memberi efek jera bagi pelaku supaya meraka bisa tobat dan tidak mengulangi lagi perbuatan yang dapat merusak masa depan perempuan dan anak.

Menurut, Mulyadi (2010), hakim harus memberikan putusan yang semaksimal mungkin tidak memihak kepada siapapun agar tidak terjadi lagi kasus-kasus perdagangan orang, Penegak hukum harus memberi putusan yang bisa memberi efek jera bagi pelaku agar bisa mengurangi kasus perdagangan orang, karna kasus perdagangan orang sangat berbahaya bagi perempuan dan anak perbuatan tersebut bisa merusak masa depan perempuan dan anak perbutan perdagangan orang susah untuk korban bisa keluar dari kasus tersebut perlu adanya bantuan dari pemerintah dan penegak hukum agar bisa korban dapat keluar dari kasus perdagangan orang.

\section{Bentuk Perlindungan Hukum terhadap Hak Korban dalam kasus Perdagangan Manusia}

Sebuah upaya yang diberikan oleh pemerintah adalah perlindungan hukum bagi para korban perdagangan orang. Segala upaya telah di keluarkan oleh pemerintah. Salah satunya adalah undangundang tentang perlindungan hukum terhadap korban perdagangan orang. Hal ini demi melindungi 
perempuan dan anak dari kasus perdagangan orang yang terjadi saat ini. Sanksi Pidana Terhadap Pelaku Perdagangan Manusia. Dengan adanya hukum di Indonesia, dapat membuat para pelaku perdagangan orang mendapat hukuman yang pantas dengan perbuatan mereka. Selain itu, dengan adanya hukuman dapat mengurangi kasus perdagangan orang terhadap perempuan dan anak. Hal ini sejalan dengan Ali (1999) bahwa dengan adanya sanksi pidana haruslah memberi sanksi yang sepadan dengan perbuatan para pelaku dan memberi efek jera bagi pelaku.

\section{SIMPULAN}

Berdasarkan pembasan di atas tentang perdagangan orang pada perempuan dan anak maka dapat di buat kesimpulan yaitu upaya perlindungan hukum terhadap perempuan yang di berikan oleh pemerintah kepada korban perdagangan orang adalah upaya yang harus di lakukan dengan baik oleh pemerintah agar bisa terwujudnya keadilan bagi para korban. Kemudian, sanksi pidana terhadap korban harus sesuai dengan perbuatan yang mereka lakukan, dan harus di berikan sanksi yang memberi efek jera bagi pelaku perdagangan orang, supaya bisa mengurangi kasus perdagangan orang.

\section{DAFTAR PUSTAKA}

Ali, C. (1999). Filsafat Hukum. Bandung: Memories Book.

Ali, M., \& Nurhidayat, S. (2011). Penyelesaian Pelanggaran HAM Berat (In Court System \& Out Court System). Depok: Gramata Publishing.

Arief, B. N. (2010). Masalah Penegakan Hukum dan Kebijakan Hukum Pidana dalam Penanggulangan Kejahatan. Jakarta: Kencana Prenada.

Dols, J. D., Beckmann-Mendez, D., McDow, J., Walker, K., \& Moon, M. D. (2019). Human Trafficking Victim Identification, Assessment, and Intervention Strategies in South Texas Emergency Departments. Journal of Emergency Nursing, 45(6), 622-633.

Dunbar, M. O. P. (2010). Pengertian Perdagangan Orang. Jakarta: Sinar Gafika.

Fong, R., \& Berger Cardoso, J. (2010). Child human trafficking victims: Challenges for the child welfare system. Evaluation and Program Planning, 33(3), 311-316.

Gerry, F., Muraszkiewicz, J., \& Iannelli, O. (2018). The drive for virtual (online) courts and the failure to consider obligations to combat human trafficking - A short note of concern on identification, protection and privacy of victims. Computer Law and Security Review, 34(4), 912-919.

Gonzalez-Pons, K. M., Gezinski, L., Morzenti, H., Hendrix, E., \& Graves, S. (2020). Exploring the Relationship between Domestic Minor Sex Trafficking Myths, Victim Identification, and Service Provision. Child Abuse and Neglect, 100(June), 104093.

Martinho, G., Gonçalves, M., \& Matos, M. (2020). Child Trafficking, Comprehensive Needs and Professional Practices: A Systematic Review. Children and Youth Services Review, 119(October), 105674.

Marzuki, P. M. (2011). Penelitian Hukum. Jakarta: Kencana Prenida Media.

Mulyadi, L. (2010). Putusan Hakim dalam Hukum Acara Pidana, Teori, Praktik, Teknik Penyusunan dan Permasalahannya. Bandung: Citra Aditya Bakti.

Mustafid, F. (2019). Perdagangan Orang dalam Perspektif HAM dan Filsafat Hukum Islam. Al-Ahkam: Jurnal Pemikiran Hukum Islam, 29(1), 85-108.

Suhardin, Y. (2008). Tinjauan Yuridis Mengenai Perdagangan Orang Dari Perspektif Hak Asasi Manusia. Mimbar Hukum - Fakultas Hukum Universitas Gadjah Mada, 20(3), 474-486.

Takariawan, A., \& Putri, S. A. (2018). Perlindungan Hukum terhadap Korban Human Trafficking dalam Perspektif Hak Asasi Manusia. Jurnal Hukum Ius Quia Iustum, 25(2), 237-255. 